\title{
CAN YALE ENDOWMENT MODEL BE APPLIED FOR ISLAMIC PENSION FUND?
}

\author{
Yunice Karina Tumewang ${ }^{1}$
}

\begin{abstract}
This paper examines Yale Endowment model and proposes a modified investment model to achieve an investment objective of mainstream investors and to comply with Sharia principle. The proposed model utilizes Islamic CAPM to formulate the optimal asset allocation for Islamic pension fund's portfolio. It will offer a strong investment strong which could be adopted by government to manage the Islamic pension fund and raise the awareness of society to see the great potential of Islamic pension fund in the future. Promoting an efficient and productive investment of pension-fund assets acts as the catalyst for achieving Sustainable Development Goals (SDGs) by providing important sources of long-term finance for development, supporting financial inclusion and ensuring that poverty among the elderly is alleviated by a strong growth and resilience of income in retirement through pension systems that have broad coverage.
\end{abstract}

Keywords: Yale Endowment Model, Islamic Pension Fund, SDGs, Ending Poverty.

JEL Classification: I32, I310, Z120

Received : September 18, 2017

Revised : April 17, 2018

Accepted : May 3, 2018

1. Durham University, United Kingdom, correspondence email: yuni.karina@gmail.com 


\section{INTRODUCTION}

"Yale's Endowment is the engine that drives the university. It supports $34 \%$ of our total operations: from the financial aid we give to our great students to our cutting edge scientific research, from our world-class professors to our unparalleled art collections. The Yale Investments Office is simply the best in the world. It not only makes our research and education possible. It is itself the home of great research and education. It trains the best investment experts on the planet. It has changed Yale and the world." (Prof. Benjamin Polak, B.A., M.A., Ph.D - Economics Expert)

The number of Muslim shows an exponential growth in recent years. Based on Pew Research Center (2015) and (Center, 2017), in the next half century Muslim is projected to experience the most significant growth among all of religious groups in the world. The global population is predicted to rise by $32 \%$ while the number of Muslims is estimated to experience superior growth by 70\%. In 2015 Muslims is predicted to account for nearly $24.1 \%$ of the world's population, while in the next 45 years they will cover three-in-ten proportion of the world. However, the United Nation predicts that the Muslim world will be increasingly filled by the elderly population. Having a closer look at Indonesia as the most populous Muslim country in the world, its population is predicted to swell to 322 million by 2050 and over 60s will triple to 62 million (United Nation, 2016). In line with this forecast, Thomson Reuters (2015) in the Global Islamic Economy Report reveals the demand for pension funds which comply with shariah principle is forecast to reach as high as US\$ 190 billion.

As a matter of fact, several studies have proved that even in the developed nations, the changing demography resulted from the increase of elderly as well as unproductive population has been a driving factor of a pension crisis (European Commission, 2012; Willetts, 2003). The ramifications of failing pension systems range from a reduction in the quality of life for the elderly to insolvencies of companies (European Commission, 2012). This case can be worse for the future of most Muslim-majority countries in the world as their economy as well as pension fund management are highly underdeveloped (Kuran, 1997). In term of the world economy, they contribute only $8.26 \%$ despite making up $23.44 \%$ of world population. On the contrary, 28 members of European Union, which accounts for only $6.94 \%$ of world population, dominate the world economy by contributing $23.53 \%$. While in term of pension fund management, most Muslim countries did not have a robust system yet. Taking an example of Indonesia, only $6.37 \%$ (4471 out of 70233 million workers) have registered for a pension program. Meanwhile according to Indonesian Financial Service Authority (OJK), in its Roadmap for Non-Bank Islamic Financial Industry 2015-2019, it shows that 74.8\% of workers and $85.7 \%$ of entrepreneurs in Indonesia have an interest in Islamic Pension Funds (Otoritas Jasa Keuangan, 2015), but this huge demand is still untapped. It, thus, becomes a mainstream problem faced by Muslim countries globally and remain obscure.

The closing gate of religious rulings in Islam (ijtihad) is considered to be a reason of under-development in several Muslim countries across the globe (Schacht, 1964). It creates a decline in political and intellectual power and further makes Muslim world difficult to cope with the dynamic changes in the current 
circumstances through institutional reforms. In the field of finance, Ebrahim et al. (2016) assert that these stagnancies are caused by the strong emphasis on purely legal perspective (so-called 'illah) of legal judgment rather than the substance of Islamic jurisdiction (Maqasid al-Shari'ah) driven by logical reasoning (wisdom). Islamic rulings should go beyond the explicit meaning of the scriptural texts by exploring the universal intent of the divine message.

Taking economic rationale into consideration, we could strongly argue that Islamic pension fund needs to figure out the most suitable model of investment to be employed for the better payoffs as a means to achieve the objective of Islamic law which lies on safeguarding diin (religion), nafs (self), aql (mind), nasb (offspring), and maal (wealth) (Al Ghazali, 1937). As proven by Kenya, pension fund could contribute to an estimated $68 \%$ of the total income of retirees (Allena and Gorton, 1996) which further control wealth estimated at Kshs. 397 billion, the equivalent of $30 \%$ of the country's GDP (Coase, 2000).

Concerning the importance of investment in thepension fund, this study will observe the Yale Endowment model as a leading fund management which generated an impressive result over these 30 years. This study aims to examine whether or not the Yale Endowment model is in line with Islamic finance principle and to closely resemble an Islamic investment model which will result in an impressive performance as Yale Endowment for a greater mashlahah (goodness) to be achieved by Muslim ummah.

This study is conducted by integrating an Islamic CAPM developed by Ebrahim et al. (1999) and mathematical analysis from The Stochastic Programming Approach to Asset, Liability, and Wealth Management (Ton, 2001). It allows us to propose an optimal investment model for long-term investors (i.e. retirement planner) who wish to achieve certain investment objective under Islamic principle and at the same time meet future obligations under Asset Liability Management framework. Promoting an efficient and productive investment of pension-fund assets not only supports the goal of providing important sources of long-term finance for development but also supporting financial inclusion and ensuring that poverty among the elderly is alleviated by a strong growth and resilience of income in retirement through pension systems that have broad coverage. To the researcher's knowledge, there was no attempt to plan financial modeling on Islamic pension fund portfolio, although the foreseeable future is promising. This work put the effort to cover up this gap.

The above introductory section provides a broader perspective of the study as well as the overall aims and motivation behind the work of this paper. Section 2 sets the scene by pointing out the economic malaise faced by Muslim world and how it connects with financial under-development which might be even worse due to the aging population if not seriously handled. Section 3 of this paper will introduce the methodology used in this paper, develops the ideal asset allocation, and provides numerical illustrations through CAPM simulation. Section 4 concludes the study by providing the limitations which constrain the adoption of the proposed model in practice. Finally, it ends with the recommendations for further development and research in this field. 


\section{LITERATURE REVIEW}

\subsection{The Role of Islamic Pension Fund}

Pension fund is gaining popularity as the world's populations are aging rapidly. In Indonesia, the most populous Muslim country in the world, its population is predicted to expand to 322 million by 2050 with the elderly population which will triple to 62 million (United Nation, 2016). While in Europe, the number of people with the age of more than 64 is forecasted to be almost double (from $20 \%$ to $40 \%$ ) during the period of 1990-2030 (Bos, 1994; Rosevaere et al. 1996). If not maintained properly, the growing number of elderly population will significantly contribute to the growing number of people just above the line of poverty and social exclusion. As seen in Table 1, by 2030 two productive citizens should be financially responsible for a pensioner as a comparison with four in 1990. There are several factors contributed to this aging phenomenon which spread across the world: better living conditions, declining fertility rates, etc.

Table 1.

Elderly Dependency Ratio

\begin{tabular}{|c|c|c|c|c|c|c|c|c|c|}
\hline \multirow{2}{*}{ Country } & \multicolumn{3}{|c|}{ Dependency Ratio } & \multicolumn{6}{|c|}{ Pension Cost as \% GDP } \\
\hline & 1990 & 2010 & 2020 & 1995 & 2000 & 2010 & 2020 & 2030 & 2040 \\
\hline Austria & 22.4 & 27.7 & 44 & & & & & & \\
\hline Belgium & 22.4 & 25.6 & 41.1 & 10.4 & 9.7 & 8.7 & 10.7 & 13.9 & 15 \\
\hline Denmark & 22.7 & 24.9 & 37.7 & 6.8 & 6.4 & 7.6 & 9.3 & 10.9 & 11.6 \\
\hline Finland & 19.7 & 24.3 & 41.1 & 10.1 & 9.5 & 10.7 & 15.2 & 17.8 & 18 \\
\hline France & 20.8 & 24.6 & 39.1 & 10.6 & 9.8 & 9.7 & 11.6 & 13.5 & 14.3 \\
\hline Germany & 21.7 & 30.3 & 49.2 & 11.1 & 11.5 & 11.8 & 12.3 & 16.5 & 18.4 \\
\hline Ireland & 18.4 & 18 & 25.3 & 3.6 & 2.9 & 2.6 & 2.7 & 2.8 & 2.9 \\
\hline Italy & 21.6 & 31.2 & 48.3 & 13.3 & 12.6 & 13.2 & 15.3 & 20.3 & 21.4 \\
\hline Netherlands & 19.1 & 24.2 & 45.1 & 6 & 5.7 & 6.1 & 8.4 & 11.2 & 12.1 \\
\hline Portugal & 19.5 & 22 & 33.5 & 7.1 & 6.9 & 8.1 & 9.6 & 13 & 15.2 \\
\hline Spain & 19.8 & 25.9 & 41 & 10 & 9.8 & 10 & 11.3 & 14.1 & 16.8 \\
\hline Sweden & 27.6 & 29.1 & 39.4 & 11.8 & 11.1 & 12.4 & 13.9 & 15 & 14.9 \\
\hline UK & 24 & 25.8 & 38.7 & 4.5 & 4.5 & 5.2 & 5.1 & 5.5 & 5 \\
\hline EU Average & 21.4 & 25.9 & 40.3 & & & & & & \\
\hline
\end{tabular}

Source: Report from Bos (1994) and Rosevaere et al. (1996)

Having a look from many different angles of life, pension plans now becomes an essential part of our life in the field of economy and social since its impact is going to experience an uptrend in the future. Pension fund will bring a significant impact on macroeconomic as well as microeconomic factors such as size the national wealth, GDP, consumption spending, its forms levels of interest rates, stock yields, etc. The level of pension saving affects the rate of capital formation and economic growth as well as for levels of production and employment.

In general, pension systems contribute significantly to the development of national financial systems (King and Levine, 1993; Bekaert, Harvey, \& Lundblad, 2001). Pension fund activities may also bring capital and financial market 
development through their role of substituting and complementing other financial institutions, in particular commercial and investment banks. Acting as intermediary competitor either for household savings or firm financing (Impavido, Musalem, and Tressel, 2002), pension funds nurture competition and improve the efficiency of the loan and primary securities markets. This results in a lower spread between lending rates and deposit rates, and lowercost of access to capital markets. In addition to that, Davis (1995) argues that pension funds could complement the role of banks by either long-term financing on debt securities or long-term investment in bank deposits. Other potential benefits can be obtained from the growth of pension funds are the inducement toward financial innovation, modernization of infrastructure in secrutity market, and improvement in financial regulations, corporate governance, financial market efficiency as well as transparency (Davis, 1995). Those impacts are expected to stimulate higher economic growth for long period of time.

Pension systems are crucial for most firms as they represent a significant part of employee compensation and a major current expense. According to data obtained from the U.S. Bureau of Labour Statistics in 2004, businesses paid employee benefits of $\$ 7.40$ for each hour their employees worked so that private pensions are $14 \%$ of these benefit costs (Popkin, 2005). Many traditional companies with Defined Benefit (DB) pension plans have faced bankruptcy due to their unfilled pension obligations. Munnell et al. (2006) provides a number of possible explanations why employers take off their DB plans. They argue that the reason why companies cut off the DB pensions is to reduce workers' total compensation driven by global competition, growing health or several inherent risks (market risk, longevity risk, and regulatory risk) in DB pension plans. A large number of DB pension plans, therefore, have been replaced by Defined Contribution (DC) plans that do not have any deferred pension obligations, pension contributions continue to be an essential part of employee benefits and significant expense.

On the other side, pensions with its sheer size also hold an important role as a financial intermediation in a country (Franzoni and Marin, 2006; Jin et al. 2006). We could take an example of US state pension which has liabilities in June 2009 amounted to $\$ 2.3$ trillion and the annual costs of pension liability amounted to 23 billion (about 1\%). Having a closer look at another perspective, according to 2010 report of Fund Management of The City UK, in 2009 global pension assets under management reached \$28 trillion which is higher than all mutual fund assets under management (\$23 trillion out of \$105 trillion in total funds under management globally). It is in line with the 2010 Global Pension Asset Study by Towers Watson, among developed countries like the UK, the USA, and Japan,the percentage of public pension assets over total funds under management varied from $11 \%, 30 \%$, and $70 \%$ respectively. Clearly, national pensions are a very large part of the financial intermediation industry.

\subsection{The Yale University Endowment Model}

Yale Endowment Model integrates asset allocation and active management by using mean-variance analysis as formulated below: 


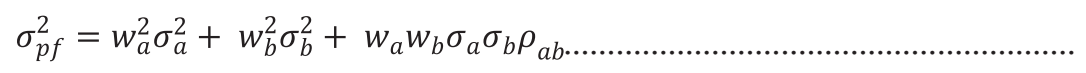

Where:

$\sigma^{2}=$ Variance

$\sigma=$ Standard Deviation

$\rho=$ Correlation of Two Assets

Yale University also moves away its endowment fund from fixed income to equity instruments due to its vulnerability to inflation. Hence, bulk of its investment (more than $90 \%$ ) is highly targeted to generate returns like equity by purchasing domestic and international equities, real estate, natural resources, absolute return instruments, leverage buyouts, and venture capital. Although one should be noted that in current investment strategy, Yale Endowment lowers its dependence on the common factor of US corporate rate profitability by lowering the heavy reliance on marketable domestic securities. As a consequence, the portfolio will be exposed to a range of less efficiently priced investment alternatives due to the asset allocation changes which could create a rich set of active management opportunities. In a nutshell, Yale's strong investment results stem from the disciplined implementation of equity-oriented asset allocation policies, combined with successful exploitation of attractive asset management opportunities.

In the field of portfolio management, the importance of asset allocation policy over active portfolio management has been extensively discussed. The work on this subject has been pioneered by (Brinson, Hood, \& Beebower, 1995) which then followed by many other studies (Ibbotson and Kaplan, 2000; Bekaert, Harvey, \& Lundblad, 2001; Vardharaj and Fabozzi, 2007). They note that policy returns are equal to more than $90 \%$ of the return of most mutual and pension fund. Nevertheless, these researches did not consider that a significant part of the two returns (fund and policy return) is driven mostly by movements of the market. Xiong, Ibbotson, Idzorek, \& Chen (2010) stated that the total return (net of all expenses and fees) of portfolio has three components including the market return, the assets allocation policy returns in excess of the market, as well as the return from active portfolio management in term of higher fees, more appropriate security selection, and better market timing).

Having a closer look at the study of Xiong, Ibbotson, Idzorek, \& Chen (2010), stressed the importance of market movements since it becomes a crucial factor influencing around $80 \%$ of the fund. Meanwhile, after stripping out the dynamic movement of the market, asset allocation policy and active asset management accounts for almost the same weight in the global return. It, then, leads to the study of performance attribution which is conceptually understandable, and its implementation is less simple. Theoretically, the market portfolio should be the alternative portfolio that "would be held by an investor who is devoid of investment judgment" (Hensel et al., 1991).

Previous literature (Brinson, Singer, \& Beebower, 1991; Ibbotson, 2010) highlighted that policy allocation accounts for the bulk of funds' performance which then leaves little room for active management. Nevertheless, their study show that explicitly considering market movements can turn out the results remarkably. Although the role of active management in global asset allocation is 
not significant, its role is much greater in describing returns to individual asset classes either traditional (equities, bonds, and cash) or alternative (real estate, private equity, hedge funds, and other strategic asset allocation).

On the other hand, several studies found that active management accounts for a substantial portion of the performance, better than policy allocation. The research conducted by Xiong, Ibbotson, Idzorek, \& Chen (2010), who studied a similar question of Brinson's research question produces a different result due to two main reasons. First, the previous work did not consider the contribution of market movements to funds' returns whereas the recent work by Ibbotson (2010) shows that market movementsare more likely to change the picture notably. Second, the research did not take care of the detailed performance level of individual asset classes where the potential benefits offered by active management can be distinctive.

During couple years ago, the pension fund industry has been gradually diversifying its claims on the real economy, away from the real claim represented by publicly traded equities towards these alternative claims. As they have gradually taken on the idea of diversification, one investment fund has frequently been held up by advisors as an example of the potential benefits of diversifying investment portfolios away from traditional asset classes: the Yale University endowment fund. Over a period of ten years to June 2009, the Yale endowment fund had generated a net return of $11.8 \%$ pa, while over twenty years to June 2009 it had generated a net return of $13.4 \%$ pa. To put this into perspective, a passive investment in a 'traditional' sterling equity/bond portfolio would have produced a gross annual return of $1.6 \%$ and $6.7 \%$ over the ten and twenty years to June 2009 respectively.

\subsection{How Could Yale University Experience an Outstanding Performance?}

Yale University adopted a diversified technique for their investment on endowment fund for more than twenty years.

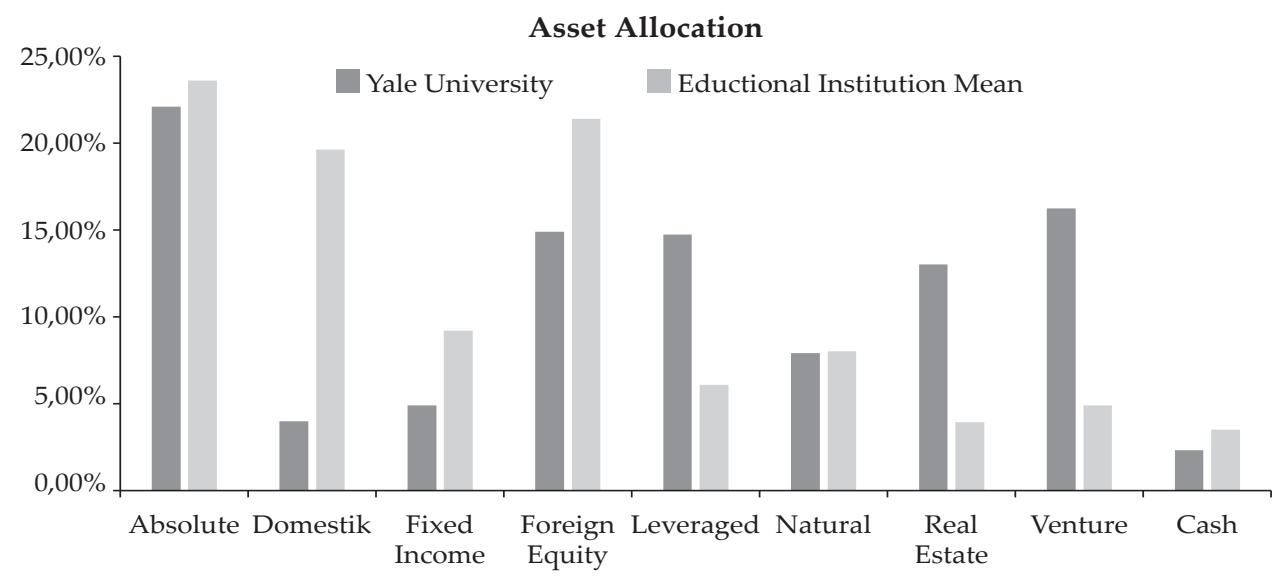

Source: Yale Endowment Report (2016)

Figure 1. Asset Allocation of Yale Endowment Fund 
Figure 1 depicts the asset allocation of Yale Endowment fund in 2016. The overall goal of having these diversified assets is to reach "the highest expected return for a given level of risk". Clearly seen that Yale's asset allocation differs from any other mainstream portfolio. It allocates $7.5 \%$ to the most developed market in the world which at the same time acts as its own domestic equities (US). Meanwhile, 9.8\% of the total allocation goes to foreign equity in which a major chunk is allocated to emerging capital markets such as Indonesia. Its allocation to fixed income which only accounts for $4.0 \%$ of the total allocation mark another significant difference compared to the allocation of other educational institutions (shown by the brown bars in the Figure 1). Overall, the top 3 asset classes which might account for nearly $100 \%$ of traditional institutional allocations are responsible for only onefifth of that.

Yale endowments pursue asset allocation strategies dramatically different from those of other educational institutions. The comparison of the average asset allocation of a broad universe of educational institutions with Yale endowment shows striking patterns. Instead of counting on traditional asset classes, Yale fund prefer to invest more in the alternative one. Almost $25 \%$ of its portfolio is invested in the instruments with absolute return, in other words investment in hedge funds. This kind of investment preference is firstly applied in 1990, and still going until now due to the fact that "absolute return investments have historically provided returns largely independent of overall market moves."

Consistently in line with its preference and priority in hedge funds, nearly a quarter of Yale's portfolio is allocated in venture capital and private equity through leverage buyout. Its investment in private equity, therefore, dwarfs its investment in publicly traded equity, and is an evidence of the Yale investment committee's belief that private equity fund managers can "exploit market inefficiencies." Finally, the fund has $32 \%$ of its assets dedicated to real assets. This portion of the fund is comprised of a variety of investments, including ones in real estate, oil and gas, and timberland. The main attraction of these investments for the Yale fund is their "inflation hedging properties." However, they also argue that the illiquid nature of these investments means that they can earn an additional return from these investments, effectively an illiquidity premium.

Conceivably illiquid assets such as real assets, private equity and absolute return instruments account for more than three-quarter of total portfolio of Yale endowment. Yale attempted to acquire illiquidity premium by creating such complicated investment in a way that accommodates the nature of illiquid assets which brings a difficulty for other investors to make an analysis. As shown in Figure 1, for more than two decades illiquid assets have generated premium much better than that from liquid assets such as public equity. For instance, return of investments on private equity can reach as much as $30.4 \%$ pa. Yale considers them as non-short-term investors with their funds are expected to achieve a particular amount of illiquidity which will further help them adding value in a way they can acquire an illiquidity premium once it appears. 


\subsection{The Evolution of Asset Liability Management}

The literature which discussed ALM model is enormous and has been started since couple decades ago by seminal work of Markowitz (1952) with mean-variance analysis which then being elaborated by the more recent extensions to include liabilities (Sharpe and Tint, 1990). Throughout the years, the idea pioneered by Markowitz has been extensively discussed by many studies across the world (see Figure 2). Harry Markowitz, the Nobel Memorial Prize winner in 1990, is widely regarded as the founder of Modern portfolio Theory which promotes the wellknown approach to portfolio allocation - "don't put all your eggs in one basket". Markowitz's portfolio theory showed how investors are ablepick and choose an optimal portfolio of assets while minimizing risk levels for certain given expected return, or maximizing expecteda return for certain level of risk. Today, this theory is what underpins multi-asset investment strategies. In the early 1950s, Markowitz introduced modern portfolio and diversification theory which might result in a lower level of risk. Nonetheless, it took more than 25 years to be applied effectively - firstly by Yale and Harvard University for their endowment fund. Asset allocation is a key factor of a successful investment strategy. Asset allocation captures the consideration of how to diversify the funds money into severaldistinct asset classes and how much amount to hold in each. To construct a portfolio to meet a specific objective, it is critical to select a combination of assets that offer the best chance to fulfill that objective with subject to the investor's preferences including investment horizon, risk appetite, etc. The combination of those assets can help to determine both the range of returns and the variability of returns for the portfolio. Built on the philosophical principles of equity orientation and diversification; asset allocation decisions provide the framework that supports the creation of effective investment portfolios.

It was not earlier than 1980s that the utilization of formal mathematical models for enhancing the financial decision making rose to widespread prominence in practice (Zenios, 1993). Globalization and innovations in the financial markets are the driving force behind this development that continues unabated to this date, aided by advances in computing technology and the availability of software. Four alternative modeling approaches have emerged as suitable frameworks for representing ALM problems Ziemba and Mulvey (1998). They are mean-variance models and downside risk, discrete-time multi-period models, continuous-time models, and stochastic programming. 


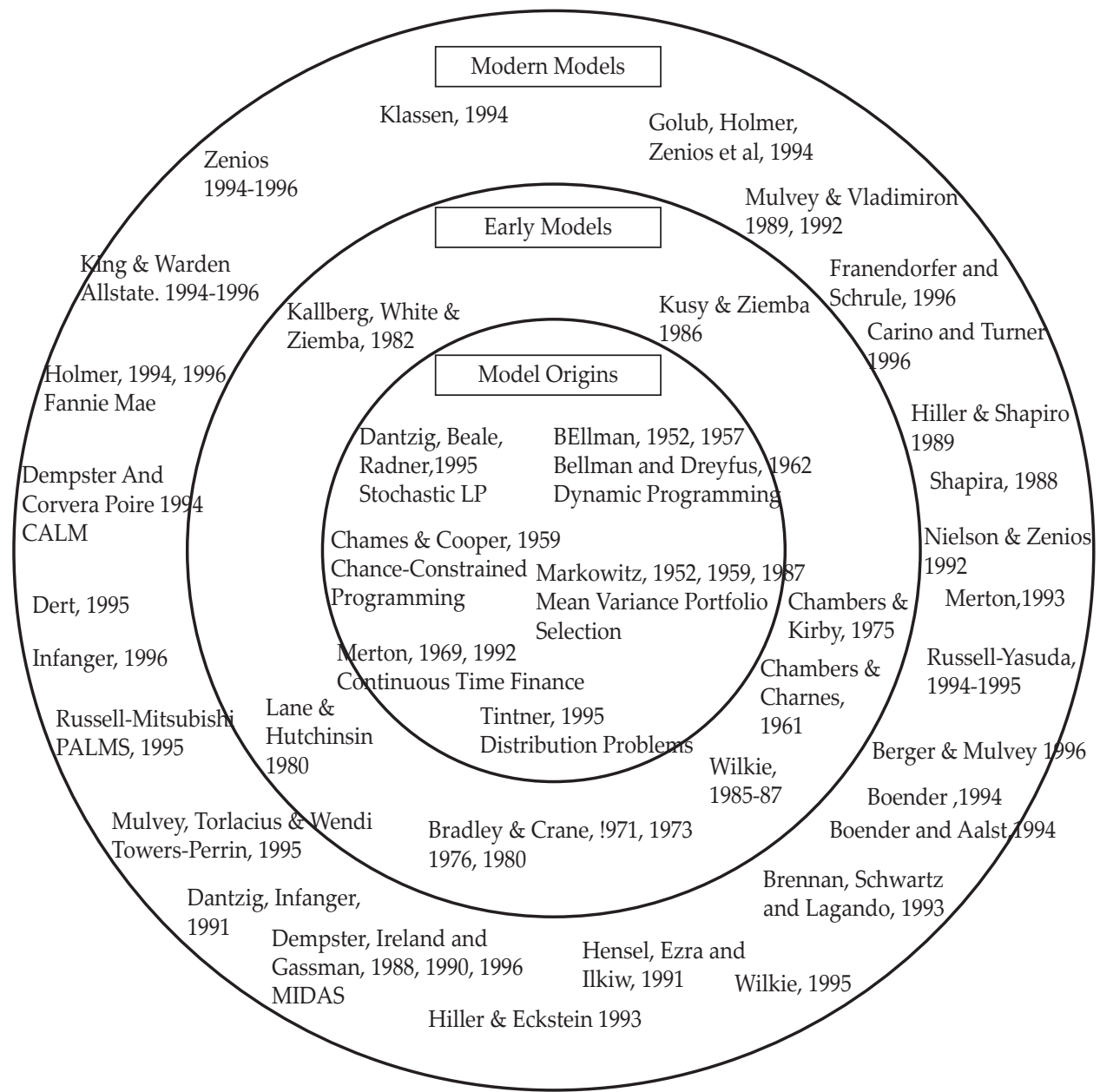

Source: Geyer \& Ziemba (2008)

Figure 2.

Evolution of "ALM"

\subsection{Investment Policy And Islamic Pension Fund}

"Investment in children's education was regarded as highly important, as there was an expectation across all age groups that children would if needed, support their parents during retirement. Investment in property emerged as the preferred and traditional way to provide income in the future and was seen as a concrete, a material investment that could be passed down the generations." (Adele Atkinson et al., 2013)

We could further note that, "Pensions, by contrast, were rarely considered or discussed, and knowledge of how they operate was low. Retirement was not at the forefront of most participants' minds; many were living month by month in terms of their spending and had not given much thought to putting money aside for their 
future, or even the age at which they might stop work. Few people were aware that pension contributions are invested, or that they could receive possible employer contributions. Most said they would opt out where they automatically enrolled in a pension scheme, primarily because their current financial circumstances would make contributions unaffordable."

Based on its result, not many respondents spontaneously put their concern on where the funds will be allocated, even though they said it would be their consideration if one promoted. One of the reasons beyond their unawareness was that they just made a deal only with the pension provider but have no business about what they will do with the funds. However nowadays as Sharia-compliant issue becomes popular and it changes people's mind about where and how the money should be invested. Sharia-compliant pension fund refers to pension fund that is being managed under the principle of Sharia law on mu'amalah (commercial as well as financial activities). One of some important principles is ensuring interest-free transaction in a way that all parties will bear the risk.

For the assurance of mentioned Islamic rulings, Sharia scholars and institutions regulated the pension funds are expected to work together in harmony in order to build and continously examine the investment policy. It ought to set clearly certain investment goals to be achieved, which are in accordance with the objective as well as the liability's characteristics of the superannuation fund. While at the same time, it also should match its tolerable risk level, plan sponsor, member \& beneficiary.

By considering the appropriate diversification and risk management, liquidity needs, obligation's maturity, and other law constraints on portfolio allocation, we need to figure out the best startegy for fulfilling the goals which meets the standard of prudent superannuation. In addition to that, we need to establish an investment policy which leastwise develop the tactical strategy by combining long-term assets with primary classifications, whole performance goals, and evaluation technique. Furthermore, if required, one could modify allocations and performance objectives with subject to the dynamic changes of market conditions and liabilities. The investment policy should broadly consider several related factorincluding trade execution, tactical asset allocation, and security selection.

Prudent risk management process which measures and looks for control portfolio risk appropriately should be established to maintain its balance sheets (assets and liabilities) coherently. The investment policy for superannuation programs has to make sure that a proper investment chocie is presented for members who is given access to the necessary information necessary forinvestment decisionmaking. Particulary it has to categorize the investment choices in accordance with the risk should be responsible by members (Ashcroft \& Stewart, 2010).

\section{MODEL DEVELOPMENT}

\subsection{Is the Yale Approach Suitable for Islamic Pension Fund?}

If we want to replicate the asset allocation of Yale endowment, we have to observe each asset class as follows:

a. Absolute Return

According to the London-based Institute of Islamic Banking and Insurance (2008), annual return of Islamic equity fund market has been able to reach 
a confident point of $12-15 \%$. With this return, the global market of Islamic equity fund is estimated to have managing assets equalled to $\$ 5$ billion. On the contrary, $\$ 28.9$ billion of funds have been allocated by the Middle-Eastbased institutional investors to hedge funds. This fund is expected to show an exponential growth of $14 \%$ ( $\$ 140$ billion out of $\$ 1$ Trillion institutional investor flows) to hedge funds by 2010. Although this future of this market looks bright, the Sharia issue of this instrument is still controversial. It, therefore, does not come up in the priority list of asset class for Islamic pension fund portfolio.

b. Domestic Equity

Equity markets in most Muslim countries are still underdeveloped. On the other side, in the developed countries such as the USA, the equity market shows an outstanding performance over the last 10 years as seen in Figure 3 below. This result has been triggered us to include this instrument in a portfolio of Islamic pension funds.

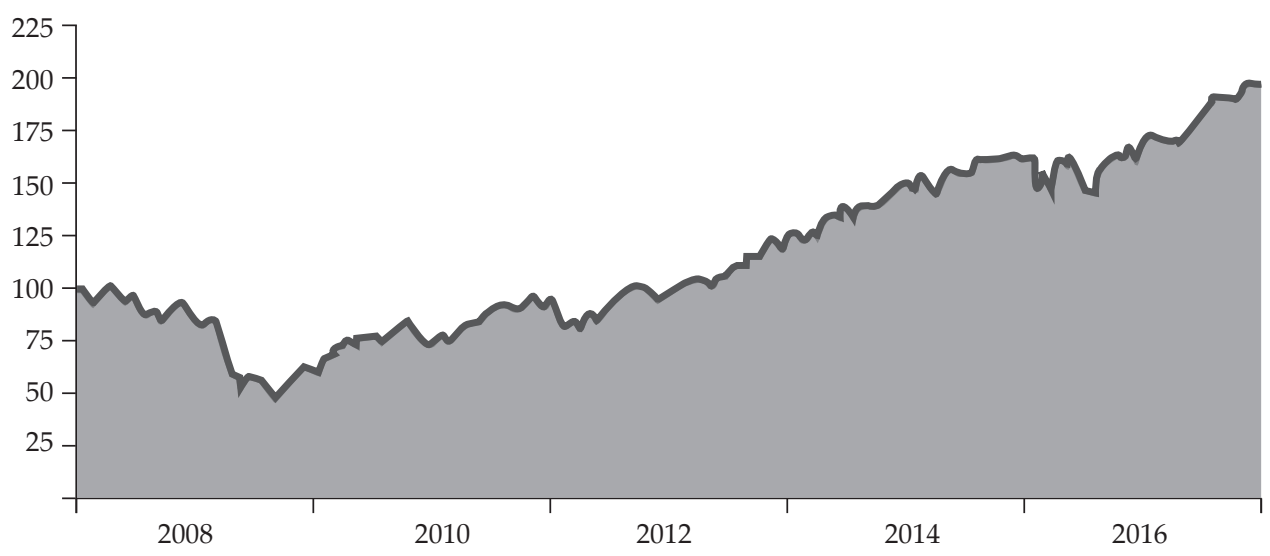

Source: S\&P 500 Market Index

Figure 3.

S\&P 500 Equity Market Performance

c. Fixed Income

In the $6^{\text {th }}$ edition of annual sukuk report, International Islamic Financial Market (IIFM) as the standard setter of Islamic Financial Services Industry shows that sukuk issuances across the globe during the year 2016 which reached around USD 88 billion experienced a substantial growth by $44 \%$ of the last year sukuk issuances which stood at USD 61 billion. The study also notes that just a handful of key markets such as Malaysia, Saudi Arabia, UAE, and Indonesia currently issued nearly 90\% of totalUSD 367 billion outstanding Sukuk. While other countries like Turkey, Pakistan and other region of Africa are going to gradually level uptheir market share in the next couple years. The research estimates the global Sukuk with an issue size of at leastUSD 100 million and tenor of more than a year which are about to mature during 2017 and 2018 will be around USD 66 billion. By taking into account investors' appetite and 
sukuk issuances in the pipeline, new sukuk will most likely be introduced to refinance these maturing Sukuk.

According to the Chairman of IIFM (2016), Sukukhold a significant role in ensuring the fulfillment of varied financing needs of the issuers including theproject and aircraft financing, monetary and budgetary management, as well as banks' capital base enhancement. He further explains that as the Sukuk market is going to evolve, there will be agrowing need for solving the various challenges that might come along as a result of the growth of any financial instrument. It, therefore, should be tackled by showing greater transparency and harmonization in the structure and the documentation of any Sharia-compliant product with respect to the Shari'ah, legal and market requirements." He further argues that "The growing confidence in Sukuk market can be seen in some of the reliable Sukuk issuing hubs, proof of which is longer dated Sukuk ranging from 30 years to perpetual issuances coming to the market".

As the second largest market in Islamic finance, the future of Sukuk market looks clearly bright, there is still a need to construct an efficient structural and financial model of Sukuk in Muslim countries. For this reason, the life-cycle Sukuk will be designed and further be developed by the prominent Professor in Islamic Finance, Professor Muhammad Shahid Ebrahim.

d. Foreign Equity

As the domestic equity is not a prospective source of investment for Muslim countries, they need to invest more in foreign equity which is highly developed such as market index of MSCI EAFE. Especially with regard to relative performance of US equities in the bull market, it reinforced the apparent inevitability of achieving superior results through investing in US stocks. Throughout much of the period, diversifying the portfolio by investing in marketable securities other than US stocks created a drag on returns.

e. Leveraged Buyouts

It can be defined as corporate acquisition through the issuance of leverage bonds or notes payable in order to cover up its cost. Under Islamic principle, the most appropriate instrument to replicate is Islamic private equity. Private equity investments tend to overcome the problems associated with divergence in aspirations of shareholders and management evident in many of today's publicly traded companies. The likelihood of failure is significantly associated with higher leverage for all firms but, clearly has to be analysed in relation to interest coverage, the capacity to service debt.

"Adequate leverage places pressures on managers to perform in order to service debt (Jensen, 1986) and can mitigate the problem of overinvestment in firms with limited growth opportunities (Dang, 2011). However, very high leverage may create debt servicing problems, particularly if cash flow projections are not met, predicted asset sales are not completed, or monetary conditions change. Higher leverage, therefore, has been associated with a high probability of failure. Favourable credit conditions are a major driver of leverage in private equity deals (Axelson et al., 2012) and, in the initial stages, optimal leverage may be high (Kortweg, 2010). The maximum amount of debt that can be sold against the firm's assets is greater in a boom due to lower 
default risks (Hackbarth et al., 2006). This implies that leverage increases insolvency risk for firms unable to adjust capital structure prior to/during the downturn or in the face of changing monetary conditions".

The above explanation trigger the rationale behind the injunction of riba which has been explained by Ebrahim et al. (2014) that ribawi contract is inefficient due to three main reasons: expropriation of wealth, financial fragility, and financial exclusion. Therefore, there is a need to figure out the alternative instrument including hybrid securities and life-cycle sukuk which further will be discussed by the well-respected Professor in Islamic Finance, Prof. Muhammad Shahid Ebrahim.

f. Natural Resources

Several research studies show that the world economy depends on the Muslim world's natural resources' exports, in particular, those of the Persian Gulf as it holds two-thirds of the planet's discovered crude oil reserves (Abdulai \& Siwar, 2011; Jason, 2013). Equity investment in natural resources - oil and gas, timberland, metals, and mining, agriculture - share common risk and return characteristics such as protection against unanticipated inflation, high and visible current cash flow, and opportunities to exploit inefficiencies. Using project finance, British Petroleum is able to develop an oil and gas platform in the North Sea by raising \$945 million, while Freeport Minerals is able to develop the Ertsberg copper mine in Indonesiaby raising \$120 million for (West Jason, 2013). Project finance gains popularity in the natural resources sector because of the easily-structured characteristic of the project since entities are legally separated from their sponsors.

g. Real Estate

Real estate holdings play a special role in institutional portfolios, provides protection against unanticipated increases in inflation. In the perspective of Islamic finance, real estate is widely considered as an investable as well astangible asset class on which to base its financial structures. As depicted in Figure 4, real estate takes the biggest chunk of most pension fund portfolios as $87 \%$ of all public and $73 \%$ of all private sector pension funds are currently having an investment in that asset class (Preqin Real Estate Report, 2016). Among 1,005 private sector pension funds and 772 public pension funds which has been observed investing in real estate, $19 \%$ and $15 \%$ respectively of all institutional investors aremore active in that asset class as compared to any other investor type (Figure 5).

In addition to that, real estate investments span the continuum from pure debt to pure equity, with those assets combining debt and equity attributes providing the diversifying characteristics necessary to justify identifying real estate as a distinct asset class (Swensen, 2009). Real Estate Investment Trust (REITs) are listed on the stock market, which not only increase their liquidity and lower the investment costs but also reduce the agency conflicts. Ebrahim et al. (2011) explain the critical role played by PMs (Participating Mortgages) in reconciling the conflict of interest of financiers and investors especially in the case of construction loans. Real estate investment should rely heavily on equity not debt as it is ribawi and not permitted under Islamic finance principle. Real estate cash flows might vary depending on the underlying characteristics of the property and market (Gitman and Joehnk, 1996). 


\section{Superannuation Investment on Real Estate \\ - Investment Status}

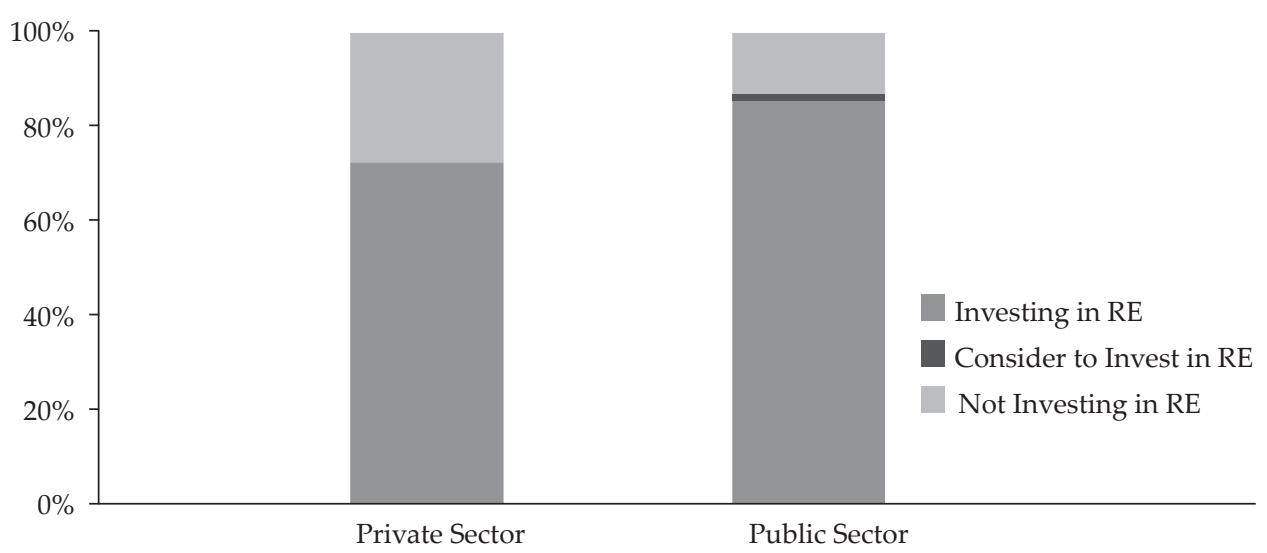

Figure 4.

Superannuation Investment on Real Estate by Its Status

\section{INSTITUTIONAL INVESTORS IN REAL ESTATE BY TYPE}

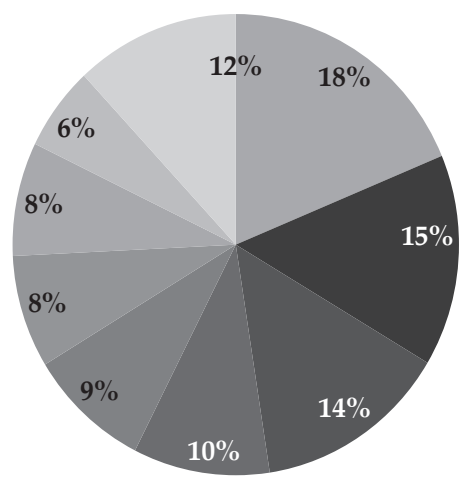

Private Pension

Family Office
Public Pension
Insurance

Foundation

Asset Manager

Endowment

Other

Figure 5.

Institutional Investor in Real Estate by Type

h. Venture Capital

Many studies (Asker et al., 2015; World's Islamic Finance Marketplace, 2015) prove that venture capital has the potential to generate high returns relative to other equity alternatives. They further explain that "The superior private equity returns come at the price of higher risk levels, as investors expose assets to greater financial leverage and more substantial operating uncertainty. From 
an Islamic point of view, venture capital is based on equity financing comform with the principle of Islamic finance as long as it invests in permissible sectors and companies with a zero conventional debt capital structure. It, therefore, integrates economic viability with Islamic preference, in order to make it a promising option for Islamic financial institutions".

The empirical result conducted by Yang et al. (2016) show that enterprise performance indicated by the participation of venture capital could bring a significant and positive impact as it will lead to a great improvement on the performance of that venture capital. On the contrary, financial leverage and corporate performance show a significant and negative correlation, which implies that debt financing, to some extent, might hinder the improvement of firm's performance. Furthermore, the study also finds that the negative impact of financial leverage on corporate performance incompanies backed by venture capital is more significant and greater. It indicates that the existence of venture capital will increase the negative effect of financial leverage on corporate performance. This result has been explained earlier by Myers \& Turnbull (1977) that when companies had more growth opportunities, the companies would take a more conservative financial leverage policy since the debt capital might lack financial flexibility and it is a fixed financial burden for the firms. Therefore, growth opportunities and debt ratios showed a reverse relationship.

i. Cash

Yale endowment just holds a limited amount of cash to have enough liquidity to meet any miscellaneous expense which is in line with the economic rationale of Islamic finance principle.

According to the above explanation, we need to carefully consider an appropriate asset class to be included in the portfolio of Islamic endowment fund. "Greater allocation to the risky asset leads to the higher volatility of the assets of pension funds, however it may also introduce a diversification effect at the total financial plus real asset value $A_{T}+V_{T}$ level, at least when the stock index is negatively correlated. When the pension fund is sufficiently funded, pensioners have no interest in the pension fund taking risks given the collateralised nature of their claims. On the other hand, the diversification effect disappears when the correlation is non-negative, which explains why $L_{0}$ then becomes a monotonically decreasing function of $\omega^{\prime \prime}$.

\subsection{Constructing a Modified Yale Endowment Model for Islamic Pension Fund}

Since Yale Endowment model is not distinct, we need to develop our own model which would gain an impressive result and suit Islamic finance principle. As private equity in the form of leverage buyout and venture capital is mostly driven by ribawi transaction since the outstanding return of private equity is resulted from the higher risk which further encourage investors to induce assets to higher level of leverage and uncertainty (Swensen, 2000). We need to shift the heavy reliance of private equity toward the more Islamic instrument such as real estate investment trust (REIT). Private equities (leverage buyout and venture capital) are inevitably linked to ribawi instrument. 
Islamic pension fund should conduct a risk/return optimization in real terms. It should be linked to the liability structure. The overall impact of investment decisions on firm and pension fund value is $L_{0}+E_{0}+D_{0}$. With a high level of debt to pensioners, the pension fund is likely to enjoy surpluses that could eventually help the sponsors repay its debt. We assume that a firm issuing a single class of debt promises a fixed payment $\mathrm{D}$ at time $\mathrm{T}$, which will have two basic equations for the flow of funds as follow:

- For the $j$ th asset category:

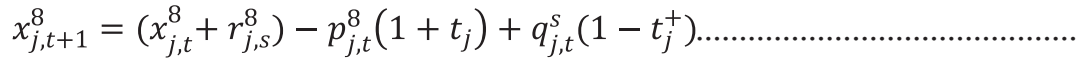

for asset $j$, time $t$, scenario $s$, where

$x_{j, t}^{8}=$ investment in asset $j$

$r_{j, s}^{8}=$ return for asset $j$,

$p_{j, t}^{j, s}=$ sales of asset $j$,

$q_{j, t}^{s}=$ purchase of asset $j$,

$t_{j} \quad=$ transaction costs for asset $j$ for time $t$ and scenario $s$.

- For the cash flows:

$x_{l, t+1}^{s}=\left(x_{l, t}^{s}+r_{l, s}^{s}\right)-\sum_{j} q_{j, t}^{s}+\sum_{j} p_{j, t}^{s}\left(1-t_{j}^{-}\right)+w_{t}^{s}-\sum_{k} y_{k, t}^{s}-\sum_{l} u_{l, t}^{s}$

Where

$u_{l, t}^{s}=$ goal payment $l$

$y_{k, t}^{s}=$ liability decision $k$

$w_{t}^{s}=$ a cash inflow at time $\mathrm{t}$, scenario s, and cash is asset category $l$.

The investment objectives of a pension fund including the Sharia-compliant one should be linked to its liability structure. It needs to conduct a risk/return optimization in real terms. In other words, it should try to maximize the real return on the portfolio, adjusted for wage inflation, consistent with a level of risk judged to be acceptable in the short run. The acceptable risk level should be set in line with liability structure of the pension fund. Instinctively, one expects that a firm without a pension fund will optimally engage in more debt, compared toan identical firm sponsoring a pension plan since the latter firm has already issued a form of debt by promising a payment to retired employees. Martellini \& Milhau (2011) found that a sponsor with a low level of outstanding debt will be the preferred choice by pensioners, as compared to a heavily indebted sponsor. The pensioners consider a more financially constrained firm will be more likely unable to afford to make additional contributions if and when needed. Andonov, Bauer, \& Cremers (2011) document that the investors which invest more in alternative asset classes than traditional one less likely to reject investment in real estate. 


\subsection{ALM Framework for Islamic Pension Fund}

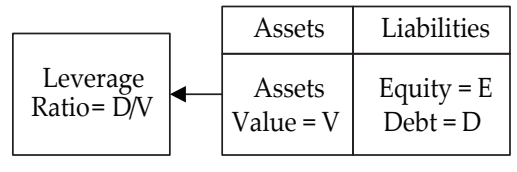

Source: Edhec Risk Institute (2012)

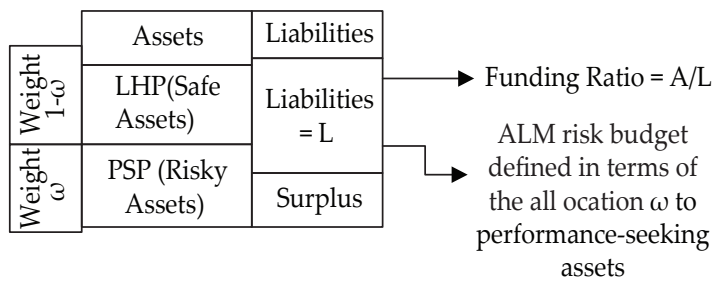

Figure 6.

Balance Sheet of the Sponsor Company and the Pension Fund

Under External Funding Regime

\section{Pension Fund}

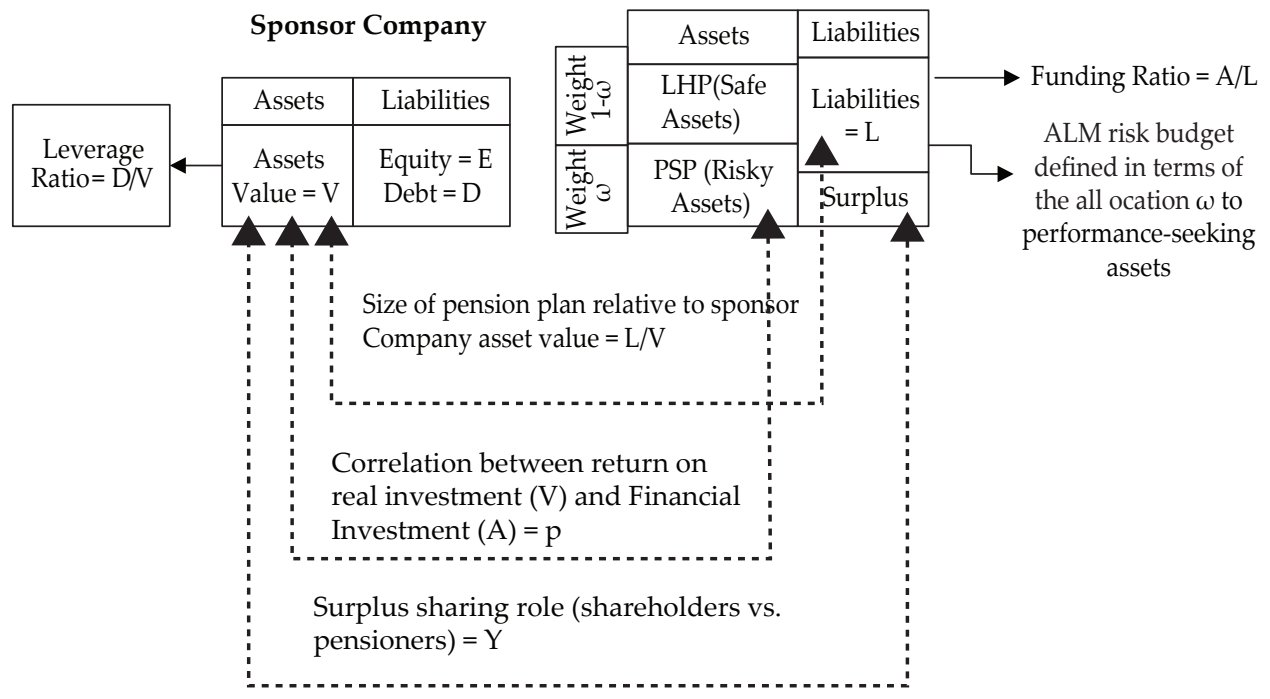

Source: Edhec Risk Institute (2012)

Figure 7.

An Integrated ALM Framework under External Funding Regime

This study uses Ziemba (2003) base-case model which draws the relationship between related parties who get involved in a pension plan including shareholders of the sponsor company, bondholders, and beneficiaries of the pension fund (workers and pensioners). This model imposes the assumption of separate balance sheets between the sponsor and the pension plan. The flow of this model can be summarized into several steps. Firstly, a debt with face value D is issued by the sponsors. At the same time, they alsoissue pension claims which are treated as a collateralised form of debt with face value L, which are held by workers and pensioners. The initial capital of the firm is allocated to funding investment 
projects (company asset value denoted by $\mathrm{V}$ ) and to funding the pension plan (pension asset value denoted by A). The pension fund allocates a fraction $\omega$ of the initial endowment to some performance-seeking portfolio (PSP) and a fraction 1- $\omega$ to some liability-hedging portfolio (LHP). In the case of poor state of economy when the assets of the pension fund A might be inadequate to fulfil the promised pension payment $\mathrm{L}$, the sponsor would make a contribution equals to the deficit $\mathrm{L}-\mathrm{A}$. If the sponsor is failed to fulfill the contribution, the default is triggered. If the pension fund enjoys a surplus, equity-holders receive a fraction $\omega$ of this surplus, which can be used to pay back bondholders. If the debt cannot be fully repaid, bankruptcy is triggered, and equity holders will receive nothing. Other incorporated factors are tax effects, bankruptcy costs, and contributions triggered by the presence of regulatory funding ratio constraints (Edhec Risk Institute, 2012). On the other scenario, without any trigger to default, the remaining assets of the pension fund, the sponsor plus their access to surpluses will be given to the equity holders.

Referring to Asset Liability Management IAIS (International Association of Insurance Supervisors) Standard No. 13 (2006), it defines as "Asset/liability management as the practice of managing a business so that decisions and actions taken with respect to assets and liabilities are coordinated". In another word, it is the process of maximizing the potential benefit of assets and cash flows to fulfill company obligations, which might reduce the firm's risk of loss due to the failure of paying a liability on time. To cut a long story short, ALM can be simply described as the process that deals with how to manage interest rate risk. While in the case of the pension plan, the essence of proper ALM should be an orchestrated event based on enhancing the pension plan's funded ratio (assets/liabilities).

With regard to the liability structure of pension fund, equity holds an essential role as first highlighted by Peskin (1997) who argues that there is a need for having an asset that would behave identically to the pension liability it funds. He further elaborates that equity exposure and plan-sponsor costs that the equity exposure of a pension fund is a great deal influencing its future contribution costs. Equityholders are allowed to acquire the full surplus of the investment on superannuation and expected to take an advantage from riskier strategies, especially for greatly funded plan.

\subsection{Numerical Illustrations}

\subsubsection{Data Assumptions}

In order to have an estimation of asset return distributions, this study used the annual historical return from 1987 to 2016 which taken from available database on DataStream Access. Equities were distinguished into US Large stocks (S\&P 500 Index), US Small Stock (S\&P Small Cap 600® Index) and International Stocks (represented by S\&P Global 100 Index). Investment on Natural Resources is represented by S\&P Global Natural Resource, while REIT is represented by US Equity REIT Index. This study calculated the correlation matrix from the historical data directly for every time series from 1987 until 2016. 


\subsubsection{An Investment Example}

After collecting and calculating the average return as well as standard deviation of riskless as well as risky assets which is inspired by asset class of Yale Endowment model and at the same time suits Sharia principle, this study utilizes the mathematical equation which is extensively discussed by several studies including Black (1972) and Lintner (1965), so-called Zero-Beta CAPM (Capital Asset Pricing Model).

$$
\begin{aligned}
& E\left(\tilde{r}_{s}\right)=\mathrm{E}\left(\tilde{r}_{z}\right)+\beta_{S M}\left[E\left(\tilde{r}_{M}\right)-E\left(\tilde{r}_{z}\right)\right], \\
& {\left[E\left(\tilde{r}_{M}\right)-E\left(\tilde{r}_{z}\right)\right]>0, \text { and } \operatorname{Cov}\left(\tilde{r}_{M}, \tilde{r}_{z}\right)=0 .}
\end{aligned}
$$

where $\tilde{r_{s}} \tilde{r_{z}}$ and $\tilde{r_{M}}$ imply the stochastic returns on the stock, the zero-beta and the market return, respectively.

Under Sharia law point of view, prohibition of riba leads us not to consider the real return on riskless assets as captured by the asset $R_{\mathrm{f}}$ which represents the lowest return in investment pecking order and is usually captured by the payoff of 3-Month Treasury Notes. For this reason, (Ebrahim, 1999) proposed an Islamic version of CAPM in which the zero-beta asset is defined as Qardh Hassan asset. Qardh Hassan facility would not run parallel to the X-axis as imposed by 'Riba alNasi'ah' facility; rather it would run along the axis. 'Riba al-Nasi'ah' is perceived to generate a real return (i.e. an excess return over inflation), on contrast, 'QardhHassan' is perceived to generate a zero-real return (i.e. a normal return equals to anticipated inflation). Under this scenario, equity in an Islamic economy can be calculated as follows:

$$
\begin{aligned}
& E\left(\tilde{r}_{\text {real return }, i}\right)=\beta_{\text {real return }, i}\left[E\left(\tilde{r}_{\text {real return }, m}\right)\right]
\end{aligned}
$$

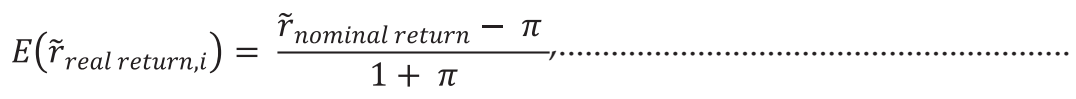

where $\pi$ is the expected rate of inflation.

Finally, it comes up with the optimal combinations of five (5) risky assets which are encouraged to be employed by shari'ah-compliant investment sorted as follows:

1. $\operatorname{REIT}(31.27 \%)$

2. Foreign Equity (23.46\%)

3. Infrastructure $(18.89 \%)$

4. US Large Stock $(18.77 \%)$

5. Natural Resources (7.61\%). 
Eff. Trade- Off Line \& Eff. Frontier Curve

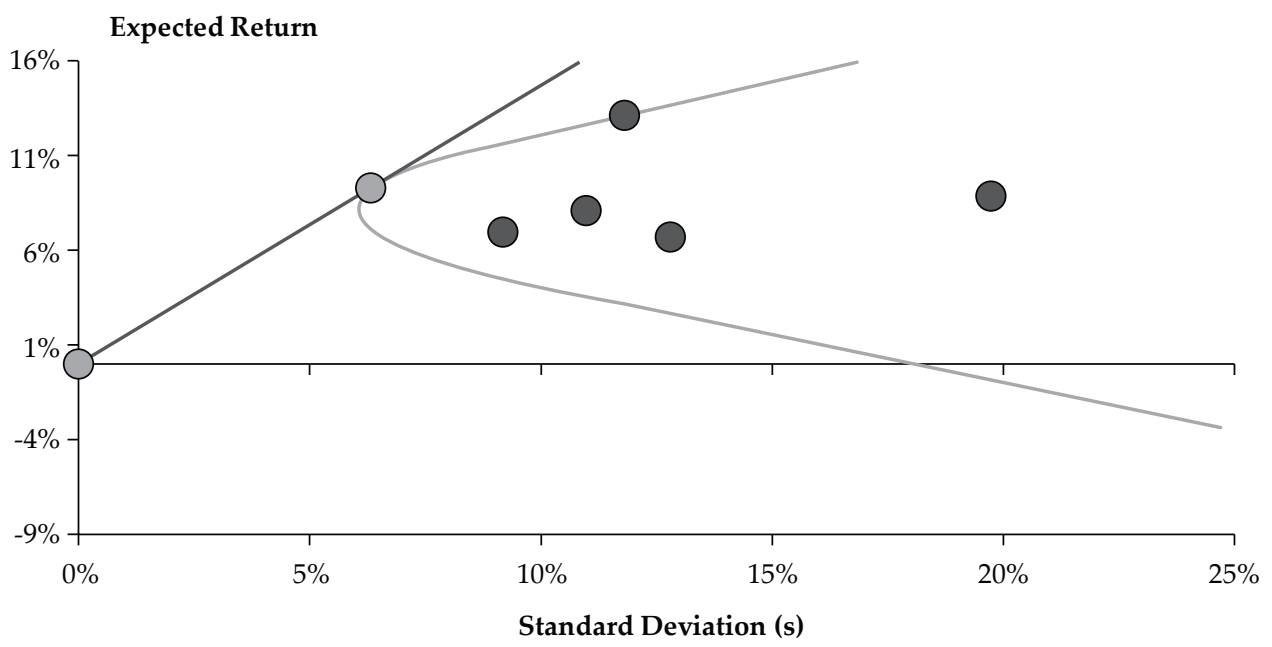

Figure 8.

CAPM Simulation

Portfolio Weights in an Optimal (Tangent) Portfolio

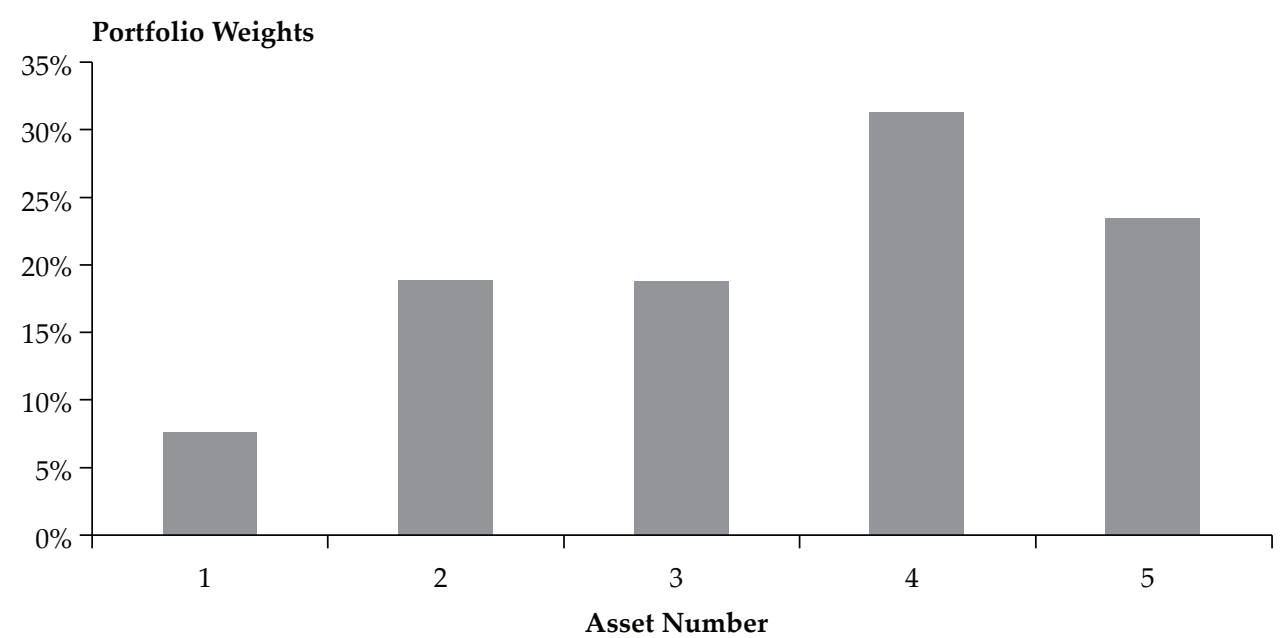

Figure 9.

Portfolio Weights in an Optimal Portfolio 
Table 2.

Expected Return and Standard Deviation

\begin{tabular}{lccc}
\hline \multicolumn{1}{c}{ Inputs } & $\begin{array}{c}\text { Expected } \\
\text { Return }\end{array}$ & $\begin{array}{c}\text { Standard } \\
\text { Deviation }\end{array}$ & {$[\mathbf{1}+\mathbf{E}(\mathbf{r})]$} \\
\hline Natural Resources & $6.37 \%$ & $12.38 \%$ & $106.37 \%$ \\
Infrastructure & $8.57 \%$ & $10.38 \%$ & $108.57 \%$ \\
US Large Stock & $8.11 \%$ & $10.97 \%$ & $108.11 \%$ \\
US Equity REIT & $12.94 \%$ & $11.80 \%$ & $112.94 \%$ \\
Foreign Equity & $6.90 \%$ & $9.17 \%$ & $106.90 \%$ \\
\hline
\end{tabular}

Table 3.

Correlation

\begin{tabular}{cccccc}
\hline & \multicolumn{5}{c}{ Correlations } \\
\cline { 2 - 6 } & $\mathbf{1}$ & $\mathbf{2}$ & $\mathbf{3}$ & $\mathbf{4}$ & $\mathbf{5}$ \\
\hline 1 & $100.00 \%$ & $12.79 \%$ & $10.39 \%$ & $14.78 \%$ & $11.43 \%$ \\
2 & $12.79 \%$ & $100.00 \%$ & $15.11 \%$ & $12.97 \%$ & $17.29 \%$ \\
3 & $10.39 \%$ & $13.19 \%$ & $100.00 \%$ & $13.28 \%$ & $11.97 \%$ \\
4 & $14.78 \%$ & $16.73 \%$ & $13.28 \%$ & $100.00 \%$ & $12.29 \%$ \\
5 & $11.43 \%$ & $13.29 \%$ & $11.97 \%$ & $12.29 \%$ & $100.00 \%$ \\
\hline
\end{tabular}

Table 4.

Variance and Covariance

\begin{tabular}{cccccc}
\hline & \multicolumn{5}{c}{ Variances and Covariances } \\
\cline { 2 - 6 } & $\mathbf{1}$ & $\mathbf{2}$ & $\mathbf{3}$ & $\mathbf{4}$ & $\mathbf{5}$ \\
\hline 1 & 0.015326 & 0.001734 & 0.001411 & 0.002159 & 0.001298 \\
2 & 0.001734 & 0.01199 & 0.001721 & 0.002162 & 0.001334 \\
3 & 0.001411 & 0.001584 & 0.012034 & 0.001719 & 0.001204 \\
4 & 0.002159 & 0.002162 & 0.001719 & 0.013924 & 0.00133 \\
5 & 0.001298 & 0.001334 & 0.001204 & 0.00133 & 0.008409 \\
\hline
\end{tabular}


Table 5.

Optimal Combinations of Risky Assets

\begin{tabular}{llcccc}
\hline Asset Class & \multicolumn{1}{c}{ Index } & $\begin{array}{c}\text { Standard } \\
\text { Deviation }\end{array}$ & $\begin{array}{c}\text { Expected } \\
\text { Return }\end{array}$ & $\begin{array}{c}\text { Asset } \\
\text { Number }\end{array}$ & $\begin{array}{c}\text { Optimal } \\
\text { Combinations } \\
\text { of Risky Assets } \\
\text { (Tangent } \\
\text { Portfolio) }\end{array}$ \\
\hline $\begin{array}{l}\text { Natural } \\
\text { Resources }\end{array}$ & $\begin{array}{l}\text { S\&P Global } \\
\text { Natural } \\
\text { Resource } \\
\text { S\&P Global } \\
\text { Infrastructure } \\
\text { Infrastructure } \\
\text { S\&P 500 Index }\end{array}$ & $12.38 \%$ & $6.37 \%$ & 1 & $7.61 \%$ \\
US Large & $18.99 \%$ & $5.64 \%$ & 2 & $18.89 \%$ \\
Stock & $\begin{array}{l}\text { SS Equity } \\
\text { REIT }\end{array}$ & $11.80 \%$ & $12.94 \%$ & 4 & $18.77 \%$ \\
FEIT & $\begin{array}{l}\text { REreign Equity } \\
\text { S\&P Global } \\
\text { 100 Index }\end{array}$ & $9.17 \%$ & $6.90 \%$ & 5 & $31.27 \%$ \\
\hline
\end{tabular}

\section{CONCLUSION}

\subsection{Contribution of The Study}

This study is an attempt to address the issue of the underdevelopment of Muslim economy by proposing a highly efficient investment model in line with the objectives of the Islamic law. In Islamic point of view, we are encouraged to be economically developed; however, the lack of ijtihad development has slowed down the economy progress of Muslim ummah. Most of the contemporary Islamic financial instruments do not have a strong and healthy financial strategy to impress and attract the potential investors. To move forward, we develop a modified Yale Endowment model which has been pioneered the successful portfolio management with an outstanding performance over the decades, and at the same comply with the principle of Islamic finance. We propose a shift from heavy reliance on private equity (i.e. leveraged buyout and venture capital) to real estate investment (i.e. direct real estate investment and REITs). We hope that our result will help maximizing the potential benefit of the huge amount of funds from Muslim ummah by allocating them to an efficient investment model. It, therefore, will create a new hope for emerging Muslim economies to achieve an impressive return on their investment thereby rejuvenating the growth and resilience of these economies and bridging them to a financially inclusive world. Hence, Islamic with its financial system will stand powerfully as the blessings for all over the world (rahmatan lil'alamin).

\subsection{Limitation of The Study}

Several factors might hinder the application of this investment model as summarized below: 
(i) Lack of the strong legal structure and the flexible regulatory system in the predominantly Muslim world which could introduce exogenous risk factors in the Sharia-compliant products;

(ii) Under-developed secondary market and low protection of trading and investor;

(iii) An indistinct local institutional investor base (Jobst, 2007); and

(iv) Lack of expert in the portfolio in the predominantly Muslim countries.

In addition to that, a more advanced mathematical analysis which considers a complex inherent risk in the Islamic financial product particularly Islamic pension funds. InnoALM model designed by Ziemba could be adopted to arrive at various forecasting models.

\subsection{Summary of The Study}

This paper is commenced by the discussion of the gap between growing numbers of Muslim population with the underdevelopment of its economy. Section 2.1 presents a link to the serious problem faced by the world including Muslim countries due to the aging population which brings up the role of Islamic pension fund. Section 2.2 discussed the investment model employed by Yale University -so called Yale Endowment Model. Following that, Section 2.3 discusses the reason behind the impressive performance achieved by Yale Endowment fund. Section 2.4 discusses the evolution of Asset Liability Management (ALM) as a widely used framework for pension fund which initially developed from mean-variance analysis deployed by Yale Endowment model. Section 2.5 provides an importance of investment policy and Islamic pension fund. Section 3.1 discusses the suitability of Yale Endowment model for Islamic pension fund. Section 3.2 draws a modified Yale Endowment Model for Islamic pension fund. Section 3.3 presents ALM framework for Islamic pension fund. Section 3.4 provides numerical illustrations by conducting a mathematical simulation of the modified Yale Endowment model under Islamic CAPM. Finally, Section 4 gives a conclusion of this paper by presenting limitations which might hinder the application of this model and combine them with the recommendation to extend the model for future research in order to cope with the more complex inherent risk in Islamic pension fund.

\subsection{Recommendation for Future Research}

The modified investment model in this study is developed under risk-neutral measure without consideration on additional risk inherited in Islamic pension fund. A more advanced model of stochastic programming could be introduced by the future research to fulfill the need of a state-of-the-art investment model in Muslim countries. 


\section{REFERENCES}

Abdulai, A. M., \& Siwar, C. (2011). Journal of economic cooperation among Islamic countries. Journal of Economic Cooperation and Development, 32(2), 97123. Retrieved from https://ukm.pure.elsevier.com/en/publications/linkingsustainable-livelihoods-to-natural-resources-and-governan

Adele Atkinson, Debbie Harrison, Flore-Anne Messy, \& Juan Yermo. (2013). Improving pension information and communication OECD survEy anD lEssOns lEarnt. Retrieved from https://www.oecd.org/daf/fin/financialeducation/TrustFund2013_OECD__ Improving_Pension_Information_and_ Communication.pdf

Andonov, A., Bauer, R. M. M. J., \& Cremers, K. J. M. (2011). Can Large Pension Funds Beat the Market? Asset Allocation, Market Timing, Security Selection, and the Limits of Liquidity. Retrieved from http://ssrn.com/abstract=1885536

Ashcroft, J., \& Stewart, F. (2010). MANAGING AND SUPERVISING RISKS IN DEFINED CONTRIBUTION PENSION SYSTEMS. Retrieved from http:// www.oecd.org/finance/private-pensions/46260971.pdf

Bekaert, G., Harvey, C., \& Lundblad, C. (2001). Does Financial Liberalization Spur Growth? https://doi.org/10.3386/w8245

Black, F. (1972). Capital Market Equilibrium with Restricted Borrowing. The Journal of Business, 45, 444-455. https://doi.org/10.2307/2351499

Brinson, G. P., Hood, L. R., \& Beebower, G. L. (1995). Determinants of Portfolio Performance. Financial Analyst Journal, 52(1), 133. Retrieved from ftp://139.82.198.57/mgarcia/Seminario/textos_preliminares/100331 brinson_ Determinants_Portfolio_Performance.pdf

Brinson, G. P., Singer, B. D., \& Beebower, G. L. (1991). Determinants of Portfolio Performance II: An Update. Financial Analysts Journal, 47, 40-48. https://doi. org/10.2307/4479432

Center, P. R. (2017). Muslims and Islam: Key findings in the U.S. and around the world. Retrieved July 16, 2017, from http://www.pewresearch.org/facttank/2017/08/09/muslims-and-islam-key-findings-in-the-u-s-and-around-theworld/\#

Ebrahim, M.-S. (1999). Integrating Islamic and Conventional Project Finance. Thunderbird International Business Review, 41(October), 583-609. Retrieved from http://eserv.uum.edu.my/login?url=http://search.ebscohost.com/login.aspx?di

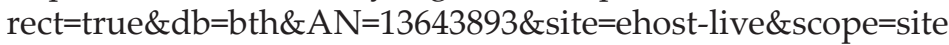

Ebrahim, M. S., Mathur, I., \& ap Gwilym, R. (2014). Integrating corporate ownership and pension fund structures: A general equilibrium approach. Journal of Banking and Finance, 49, 553-569. https://doi.org/10.1016/j.jbankfin.2014.05.032

Ebrahim, M. S., Shackleton, M. B., \& Wojakowski, R. M. (2011). Participating mortgages and the efficiency of financial intermediation. Journal of Banking and Finance, 35(11), 3042-3054. https://doi.org/10.1016/j.jbankfin.2011.04.008

Edhec Risk Institute. (2012). Pension Fund Investment in Social Infrastructure Insights from the 2012 reform of the private finance initiative in the United Kingdom. EDHEC. Retrieved from http://www.edhec-risk.com/latest_news/featured_ analysis/RISKArticle.2012-02-23.5736/attachments/120223-2 EP Pension Fund Investment in Social Infrastructure.pdf 
European Commission. (2012). The 2012 Ageing Report.https://doi.org/10.2765/19991 Ibbotson, R. G. (2010). Perspectives: The Importance of Asset Allocation. Financial Analysts Journal, 66(2), 371-382. https://doi.org/10.2469/faj.v66.n2.4

Jobst, A. A. (2007). It's all in the data - consistent operational risk measurement and regulation. Journal of Financial Regulation and Compliance, 15(4), 423-449. https://doi.org/10.1108/13581980710835272

Kuran, T. (1997). Islam and Underdevelopment: An Old Puzzle Revisited. Journal of Institutional and Theoretical Economics (JITE) / Zeitschrift FE\#\#fc;r Die Gesamte Staatswissenschaft. https://doi.org/10.2307/40752985

Lintner, J. (1965). The Valuation of Risk Assets and the Selection of Risky Investments in Stock Portfolios and Capital Budgets. The Review of Economics and Statistics, 47(1), 13. https://doi.org/10.2307/1924119

Martellini, L., \& Milhau, V. (2011). An Integrated Approach to Asset-Liability Management : Capital Structure Choices, Pension Fund Allocation Decisions , and the Rational Pricing of Liability Streams Table of Contents. Structure, (June).

Myers, S. C., \& Turnbull, S. M. (1977). Capital Budgeting and the Capital Asset Pricing Model: Good News and Bad News. The Journal of Finance, 32(2), 321. https://doi.org/10.2307/2326764

Otoritas Jasa Keuangan. (2015). Roadmap IKNB Syariah 2015-2019.

Pew Research Center. (2015). Why Muslims are the world's fastest-growing religious group I Pew Research Center. Pew Research Center. Retrieved from http://www.pewresearch.org/fact-tank/2017/04/06/why-muslims-are-theworlds-fastest-growing-religious-group/

Reuters, T. (2015). State of the GLOBAL ISLAMIC ECONOMY. Global Islamic Economy Report. https://doi.org/10.1017/CBO9781107415324.004

Swensen, D. F. (2009). Pioneering portfolio management : an unconventional approach to institutional investment. Yale: Free Press.

Ton, V. (2001). Worldwide Asset and Liability Modeling. Journal of Finance.

United Nation. (2016). Indonesia: Govt to introduce Islamic pension funds. Retrieved October 24, 2017, from http://www3.asiainsurancereview.com/ News/View-NewsLetter-Article?id=35659\&Type=eDaily\#

Willetts, D. (2003). OLD EUROPE? DEMOGRAPHIC CHANGE AND PENSION REFORM. London. Retrieved from http://www.cer.eu/sites/default/files/ publications/attachments/pdf/2011/p475_old_demo_pension-1652.pdf

Wojakowski, R. M., Ebrahim, M. S., \& Shackleton, M. B. (2016). Reducing the impact of real estate foreclosures with Amortizing Participation Mortgages. Journal of Banking and Finance, 71, 62-74. https://doi.org/10.1016/j.jbankfin.2016.05.005

Xiong, J. X., Ibbotson, R. G., Idzorek, T. M., \& Chen, P. (2010). The equal importance of asset allocation and active management. Financial Analysts Journal, 66(2), 22-30. https://doi.org/10.2469/faj.v66.n2.7

Yale Endowment Report. (2016). Yale Endowment. Yale. Retrieved from https:// static1.squarespace.com/static/55db7b87e4b0dca22fba2438/t/58ece6bd579fb35 6c857e2a4/1491920595529/Yale_Endowment_16.pdf

Ziemba, W. T. (2003). The Stochastic Programming Approach to Asset, Liability and Wealth Management. Management. 